\title{
Fatal agranulocytosis associated with Metamizole treatment in a 16-year-old girl
}

\section{Packo Dieu-le-veut Saint-Cyr Sylvestre ${ }^{1 *}$, Nanho Danho Clotaire ${ }^{1}$, N'dhatz Comoe Emeraude ${ }^{1}$, Boidy Kouakou ${ }^{1}$, Camengo Police Serge Magloire ${ }^{2}$, Diakité Mamady ${ }^{3}$, Mbelesso Pascal ${ }^{4}$ and Koffi Kouassi Gustave ${ }^{1}$}

\author{
'Department of Clinical Hematology, Yopougon Teaching Hospital, Abidjan, Côte d'Ivoire \\ 2Department of Hepato-Gastroenterology, "Amitié sino-Centrafricaine" Teaching Hospital, Central \\ African Republic \\ ${ }^{3}$ Department of Clinical Hematology, DONKA Teaching Hospital, Guinea Conakry \\ ${ }^{4}$ Department of Neurology, "Amitié sino-Centrafricaine" Teaching Hospital, Central African Republic
}

\section{More Information}

*Address for Correspondence: Packo Dieu-leVeut Saint-Cyr Sylvestre, Department of Clinical Hematology, Yopougon Teaching Hospital, Abidjan, Côte d'Ivoire, Tel: 0022589542209; Email: stcyrpacko@yahoo.fr

Submitted: 20 September 2019

Approved: 01 October 2019

Published: 02 October 2019

How to cite this article: Saint-Cyr Sylvestre PD, Clotaire ND, Emeraude NC, Kouakou B, Magloire CPS, et al. Fatal agranulocytosis associated with Metamizole treatment in a 16-year-old girl. Arch Case Rep. 2019; 3: 035-037.

DOI: dx.doi.org/10.29328/journal.acr.1001019

Copyright: () 2019 Saint-Cyr Sylvestre PD, et al This is an open access article distributed under the Creative Commons Attribution License, which permits unrestricted use, distribution, and reproduction in any medium, provided the original work is properly cited

Keywords: Agranulocytosis; Novalgin

\section{Abstract}

Agranulocytosis is one of the common reasons of consultation in hematology. It's lifethreatening because of an infection risk. The metamizole is a drug, known for its potential rare danger of inducing a severe agranulocytosis. However, it remains widely used because of its beneficial effect analgesic and antipyretic. We report in this study, a case of a girl who was 16 years old, referred for severe agranulocytosis, and appeared two weeks after treatment with Novalgin. The clinico-biological symptoms were dominated by Streptococcal septicemia with an infectious pulmonary and digestive focus. The blood cell count confirmed a severe agranulocytosis with total disappearance of neutrophils. Despite broad-spectrum antibiotic therapy and stimulation with hematopoietic growth factor, the clinical evolution was fatal in the short term. What motivates us to add this case to those of the literature in order to remind practitioners about the danger of this drug, and to promote has doubled of vigilance during use.

\section{Introduction}

The term agranulocytosis indicates a total absence of neutrophils in the peripheral blood. In practice, it's used when this number is less to $0,5 \mathrm{~g} / \mathrm{l}[1]$. This is one of the most reasons of consultation in hematology with a variety of etiologies. Among the causes, the drug-induced agranulocytosis is common. Novalgin, known as metamizole, has been on sale since 1922 [2]. Its use has been banned in the United States since 1977 by the Food and Drug Administration and then in several European countries because of its potential danger capable to induce fatal agranulocytosis [3,4]. However, it's still used in many countries of Africa, Asia and Europe by many medical specialties because of its analgesic and antipyretic action. We report in this study, a case of severe agranulocytosis revealed by septicemia with pulmonary and digestive focus, fatal in a girl of 16 year old. Through this case report, we want to promote the vigilance of medical practitioners about this known deadly drug.

\section{Case Report}

A girl student of 16-year-old was suffered from pain of ankle after a sporting activity. She had consulted a health center closest to her locality whose prescribed metamizol $1500 \mathrm{mg}$ for three times a day. Two weeks later, a fever, a physical asthenia, a general malaise and myalgia were appeared. She had consulted again the general hospital of her locality. Biological examinations noted a high level of Creatin Reactive Protein greater than $96 \mathrm{mg} / \mathrm{l}$. The test of malaria was negative. The blood cell count exam noted unexpectedly a total absence of neutrophils with leukocytes number at 3,78 $\mathrm{g} / \mathrm{l}$. The level of hemoglobin was $14 \mathrm{~g} / \mathrm{dl}$ and the platelets number at $30 \mathrm{~g} / \mathrm{l}$. She was referred later, to our department for a management. The clinical examination noted a patient consciousness with average state general. Index performance status of World Health Organization (WHO) was 2. We noted a fever with $40^{\circ} \mathrm{C}$, a sclerotic jaundice and a respiratory rate at $30 \mathrm{cycle} / \mathrm{min}$. Examination of the digestive tract noted an oral 
candidiasis with no particularity in abdomen exam (Figure 1). We noted a splenomegaly type I according to Hacket stadification. Pulmonary examination revealed crackling rales in both lungs.

Biologically, the new blood cell count exam confirmed agranulocytosis with total disappearance of neutrophils with $3,99 \mathrm{~g} / \mathrm{l}$ of leukocytes number, an anemia with hemoglobin level at $7 \mathrm{~g} / \mathrm{dl}$, a thrombocytopenia with platelets number at $30 \mathrm{~g} / \mathrm{l}$ and a of reticulocytes at $190 \mathrm{~g} / \mathrm{l}$. The table I summarizes the series of blood cell counts exam of our patient. The biochemical report confirmed hemolytic syndrome with a blood level of conjugate bilirubin at $10 \mathrm{mg} / \mathrm{l}$ and a blood level of total bilirubin $26 \mathrm{mg} / \mathrm{l}$. The exam for renal and hepatic function were strictly normal. The blood procalcitonin level was very high to $12 \mathrm{mg} / \mathrm{l}$. The blood culture isolated a streptococcus pneumonia. The radiography noted pulmonary opacities in both lungs (Figure 2).

These biological results allowed us to evoke a septicemia with an infectious lung and digestive focus. We had hospitalized the patient in the isolation room and treated with triple antibiotic combining amoxicillin-clavulanic acid $3 \mathrm{~g} /$ days, a gentamycin $160 \mathrm{mg} /$ days and Metronidazole $1500 \mathrm{mg} /$ days. This treatment was accompanied by a vascular filling with cristaloid $1 \mathrm{l}$ /day, a blood transfusion $500 \mathrm{ml}$ and the stimulation of hematopoiesis with injection of G-CSF $300 \mathrm{mg} /$ day. The evolution three day after was marked by persistence of clinical symptoms, an increase in the number of neutrophils at $0.1 \mathrm{~g} / \mathrm{l}$, leukocytes number at $4 \mathrm{~g} / \mathrm{l}$, hemoglobin at $9 \mathrm{~g} / \mathrm{dl}$, and number of platelets at $100 \mathrm{~g} / \mathrm{l}$. the patient had died on the $4^{\text {th }}$ day in a severe septicemia chart and renal failure (Table 1).

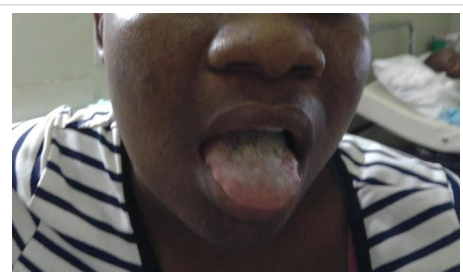

Figure 1: Oral Candidiasis.

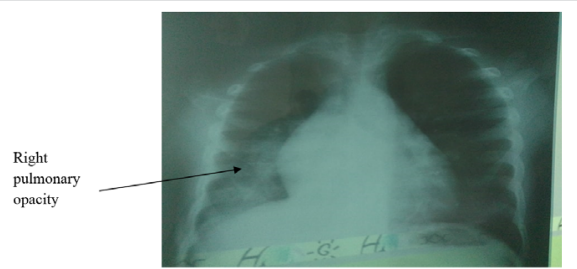

Figure 2: Right pulmonary opacity.

\begin{tabular}{|c|c|c|c|}
\hline \multicolumn{1}{|l|}{ Table 1: Serial blood cell counts. } \\
\hline Leukocytes (G/L) & Day 1 & Day 2 & Day 3 \\
\hline Hemoglobin level (g/dl) & 3,99 & 4,1 & 4 \\
\hline Lymphocytes (G/L) & 7 & 7,8 & 9 \\
\hline Neutrophils (G/L) & 3,1 & 3,4 & 3,7 \\
\hline Blood platelets (G/L) & 0 & 0,1 & 0,2 \\
\hline
\end{tabular}

\section{Discussion}

The term agranulocytosis is defined by total disappearance of neutrophils in the peripheral blood. It is used in practice when this number is less than 0,5 g/l [1]. According to the World Health Organization, the risk of infection is high if the number of neutrophils is less than $0,5 \mathrm{~g} / \mathrm{l}$ and greater if it is below 0,1 g/l [5]. The etiologies are numerous among which have been imputed some drugs. Drug-agranulocytosis is characterized by a severe and selective decrease of neutrophils in the circulating blood [1]. Metamizol is a drug belonging to the noramidopyrin family, the therapeutic class of opioid analgesics. It is known for its potential danger of causing fatal agranulocytosis. According to the WHO, novalgin-induced agranulocytosis accounts for $4.6 \%$ of all cases of agranulocytosis [6]. The first case was described in the United States in the years 1936 [7]. What had motivated its withdrawal in the United States and England. The reason for this withdrawal remains controversial by some authors, so that novalgin remains in use in some African countries, Germany, Asia and a parts of the United States [8-10]. According to Salama, et al., the mechanism by which navalgin induces agranulocytosis is immunological [11]. According to him, it's characterized by its rapid onset and severity [1]. What is found in our patient, with severe agranulocytosis until disappearance of neutrophils within two weeks of appearance. In addition, some authors have suggested that the symptoms accompanied the agranulocytosis of immunological mechanism are fever, asthenia and myalgia [1]. These symptoms were found in our patient. Furthermore, our patient had oral thrush, a lung infection that is associated with sepsis. The major infectious risk was reported by WHO with less than $0,1 \mathrm{~g} / \mathrm{l}$ of neutrophils, similar to our patient [5]. Therapeutically, the management consisted to stop the drug responsible, the broad-spectrum antibiotic therapy, antiinfective measures and the use of growth factors $[1,3,4,12]$. Generally the evolution is favorable with rapid correction of agranulocytosis $[1,8]$. What is seen in our patient in whom the number of neutrophils was increased rapidly in the first week. The fatal development in our series would be the fact that she had consulted late, at the stage of severe sepsis and the isolation room is not performing in our department that was causing her death.

\section{Conclusion}

We report a case of a fatal agranulocytosis related to the use of metamizol to promote vigilance during its use.

\section{Acknowledgement}

Our thanks to all team of Clinical Hematology for their contribution during the management of this patient.

\section{Authors contributions}

After the controversies over the death of this patient during a medical meeting, Danho Nanho Clotaire recommended 
PACKO Dieu le veut Saint-cyr Sylvestre to write this manuscript. Camengo Police SM, Diakite M, Mbelesso P were in charge of bibliographic research. Boidy Kouakou, N'dhatz Comoe Emmeraude, contributed to the care of the patient during her hospitalization. Professor Koffi Kouassi Gustave participated in the correction of the article and its scientific orientation.

\section{References}

1. Fillet, Georges. Agranulocytose médicamenteuse. Méd et hyg. 1984; 42: 2533-2541.

2. Bassetti S. Absence of evidence is not evidence of absence. In Forum Médical Suisse 2017; 17: 1059-1060.

3. Garcia S, Canionero M, Lopes G. Dipyrone-induced granulocytopenia: a case for awareness. Pharmacotherapy. 2006; 26: 440-442.

PubMed: https://www.ncbi.nlm.nih.gov/pubmed/16503727

4. Haschke M, Liechti ME. Métamizole: bénéfices et risques par rapport au paracétamol et aux AINS. Forum Med Suisse. 2017; 17: 1067-1073.

5. Gupta BMD. Rapport sur un cas mortel d'agranulocytose. Ind Med Gaz. 1936; 71: 589-590.

PubMed: 29013107; PubMed Central PMCID: PMC5170691.

6. Rollason V, Desmeules JA. Use of metamizole in children and the risk of agranulocytosis. Is the benefit worth the risk? Eur J Anaesthesiol.
2015; 32: 837-848.

PubMed: https://www.ncbi.nlm.nih.gov/pubmed/26509242

7. Benjamin J, Biederman J. Agranulocytic leukopenia induced by a drug related to aminopyrine. J Am Med. 1936; 107: 493-494.

8. Fieler M, Eich C, Becke K, Badelt G, Leimkühler K, et al. Metamizole for postoperative pain therapy in 1177 children. A prospective, multicentre, observational, post authorisation safety study. Eur J Anaesthesiol 2015; 32: 839-843.

PubMed: https://www.ncbi.nlm.nih.gov/pubmed/26086280

9. Altman D, Bland J. Absence of evidence is not evidence of absence. $\mathrm{Br}$ Med Journ 1995; 311: 485.

10. Huber M, Andersohn F, Sarganas G, Bronder E, Klimpel A, et al. Metamizole-induced agranulocytosis revisited: results from the prospective Berlin Case-Control Surveillance Study. Eur J Clin Pharmacol 2015; 71: 219-227.

PubMed: https://www.ncbi.nlm.nih.gov/pubmed/25378038

11. Salama A, Schtz B, Kiefel V, Breithaupt $H$, Mueller-Eckhardt C. Immunemediated agranulocytosis related to drugs and their metabolites: mode of sensitization and heterogeneity of antibodies. $\mathrm{Br} \mathrm{J}$ Haematol 1989; 72: 127-132.

PubMed: https://www.ncbi.nlm.nih.gov/pubmed/2788011

12. Paitel JF, Stockemer V, Dorvaux V, Witz F, Guerci A, et al. Agranulocytoses aiguës médicamenteuses. Etude clinique à propos de 30 patients et évolution des étiologies sur 2 décennies. Rev méd int. 1995; 16: 495-499. 